\title{
Effects of alfalfa hay inclusion rate on productivity of lactating dairy cattle fed wet corn gluten feed-based diets ${ }^{1,2}$
}

\author{
C. R. Mullins, ${ }^{*}$ K. N. Grigsby, $†$ and B. J. Bradford ${ }^{* 3}$ \\ *Department of Animal Sciences and Industry, Kansas State University, Manhattan 66506 \\ †Cargill Incorporated, Blair, NE 68008
}

\begin{abstract}
An experiment was conducted to evaluate the effects of varying the alfalfa inclusion rate in diets containing $31 \%$ (dry matter basis) wet corn gluten feed (Sweet Bran, Cargill Inc.). Eighty primiparous and multiparous Holstein cows averaging $178 \pm 90 \mathrm{~d}$ in milk (mean $\pm \mathrm{SD}$ ) were randomly assigned to 1 of 4 sequences in a $4 \times 4$ Latin square design with 28 -d periods. Treatments were diets containing $0,7,14$, or $21 \%$ alfalfa on a dry matter basis, with corn silage, corn grain, soybean meal, expeller soybean meal, and mineral supplements varying across diets to maintain uniform nutrient densities. Diets were formulated for similar crude protein, neutral detergent fiber, and nonfiber carbohydrate concentrations. Feed intake, milk production, body weight, and body condition score were monitored, and linear and quadratic effects of increasing the alfalfa inclusion rate were assessed using mixed model analysis. As the alfalfa inclusion rate increased, dry matter intake tended to increase linearly $(26.7,27.3,27.4$, and 27.5 $\mathrm{kg} / \mathrm{d}$ for $0,7,14$, and $21 \%$ alfalfa, respectively), and solids-corrected milk $(29.9,30.2,30.8$, and $30.5 \mathrm{~kg} / \mathrm{d})$ and energy-corrected milk production $(32.9,33.3,33.8$, and $33.6 \mathrm{~kg} / \mathrm{d}$ ) tended to increase linearly. Body weight gain decreased linearly $(22.9,18.0,11.2$, and $9.5 \mathrm{~kg} / 28 \mathrm{~d})$ with increasing alfalfa inclusion rate. Although increasing the inclusion rate of alfalfa increased the proportion of large particles in the diets, treatments had no effect on milk fat yield or concentration. Feeding more alfalfa (up to $21 \%$ of dry matter) tended to increase milk yield while decreasing body weight gain, suggesting that metabolizable energy utilization shifted from body weight gain to milk production in these treatments. However,
\end{abstract}

\footnotetext{
Received November 6, 2008.

Accepted March 11, 2009.

${ }^{1}$ Presented in part at the American Dairy Science Association annual meeting, July 2008, Indianapolis, IN [Mullins, C.R., K. N. Grigsby, and B. J. Bradford. 2008. Effects of alfalfa inclusion rate on productivity of lactating dairy cattle fed wet corn gluten feed based diets. J. Dairy Sci. 91(E Suppl. 1):121. (Abstr.)].

${ }^{2}$ Contribution no. 09-141-J from the Kansas Agricultural Experiment Station.

${ }^{3}$ Corresponding author: bbradfor@ksu.edu
}

adding alfalfa to the diet had only minor effects on productivity.

Key words: by-product, dairy cattle, alfalfa, wet corn gluten feed

\section{INTRODUCTION}

Alfalfa is a cool-season perennial legume that serves as a source of protein and fiber in dairy cattle rations. Dairy nutritionists have traditionally relied heavily on alfalfa; results from a 1995 survey revealed that $62 \%$ of dairy cattle in the United States were fed alfalfa (Mowrey and Spain, 1999). Since 1995, however, the number of acres devoted to alfalfa production has declined by nearly 4 million acres (National Agricultural Statistics Service, 2008). Not surprisingly, as the availability of alfalfa has decreased, its cost has increased by nearly $50 \%$ in the last $20 \mathrm{yr}$ (National Agricultural Statistics Service, 2008). Increased pressure for land use, including greater use of corn in the corn milling industry, has contributed to the loss of alfalfa acres. As a result, nutritionists and producers are reconsidering the role of alfalfa in dairy rations.

Scientific reports as far back as 1933 show that diets using corn silage (CS) as the only forage can support milk and milk fat production equivalent to diets incorporating both alfalfa hay (AH) and CS (Hayden et al., 1933). Thomas et al. (1970) reported that cows fed CS or $\mathrm{AH}$ as the only roughage source produced similar amounts of FCM across 3 lactations. More recent studies have also supported the conclusion that diets can be formulated to support high milk production without the use of AH (Kleinschmit et al., 2007; Kowsar et al., 2008).

Although an increasing amount of corn is being consumed by the corn milling industry, coproducts of this industry provide an opportunity for dairy producers to adopt novel diet formulation strategies. One such coproduct, produced from the wet-milling process, is wet corn gluten feed (WCGF). Wet corn gluten feed is a high-fiber, low-lignin feedstuff that can be easily incorporated into dairy cattle diets (NRC, 2001; Wickersham et al., 2004). Armentano and Dentine (1988) 
found that feeding WCGF at up to $36 \%$ of ration DM did not affect milk production, composition, or DMI in one study. On the other hand, Staples et al. (1984) showed a decrease in DMI and milk yield but an increase in milk fat percentage when WCGF was fed at high levels. It is important to note that in both studies, diets contained large proportions of forage and that WCGF was used in place of concentrates, resulting in higher dietary NDF concentrations as WCGF was added. In contrast, Kononoff et al. (2006) found that feeding a ration containing 38\% WCGF (DM basis) decreased milk fat concentration but increased milk yield, resulting in similar milk fat yields across treatments. In this study, forage decreased from approximately $60 \%$ of ration DM in the control to $38 \%$ of $\mathrm{DM}$ for the treatment diet (Kononoff et al., 2006).

It is possible to chemically balance a ration that includes large amounts of WCGF, but physical characteristics of the TMR must be accounted for. Although WCGF is relatively high in fiber, the small fiber particles provide little physically effective fiber; physically effective NDF of WCGF was reported as $11 \%$ of NDF based on rumination time and ruminal $\mathrm{pH}$ of lactating cows (Allen and Grant, 2000). Many investigators have shown that physically effective fiber is necessary for maintaining proper rumen function and preventing milk fat depression (Lammers et al., 1996; Mertens, 1997). In ruminants, physically effective fiber stimulates rumination, which facilitates the secretion of saliva that, in turn, buffers the rumen (Kay, 1966). Because of the mechanical stimulation provided by $\mathrm{AH}$ particles, feeding high levels of WCGF without AH could lead to milk fat depression. Therefore, the objective of this study was to evaluate the effects of varying $\mathrm{AH}$ inclusion rate, in diets containing 31\% WCGF, on milk and milk fat yield and BW gain.

\section{MATERIALS AND METHODS}

Experimental procedures were approved by the Institutional Animal Care and Use Committee at Kansas State University.

\section{Design and Treatments}

Forty-one primiparous and 39 multiparous Holstein cows $(178 \pm 90$ DIM; $1.8 \pm 0.99$ lactations; mean \pm SD) from the Kansas State University Dairy Cattle Teaching and Research Facility were randomly assigned to 1 of 8 free-stall pens. After initial pen assignments, variation in pen means for DIM, milk yield, and parity were assessed, and the randomization was repeated until the coefficient of variation for all 3 variables declined below $25 \%$. Each pen was assigned randomly to one of
Table 1. Composition of corn silage (CS) and alfalfa hay (AH)

\begin{tabular}{lrc}
\hline & \multicolumn{2}{c}{ Ingredient } \\
\cline { 2 - 3 } Nutrient $^{1}$ & CS & AH \\
\hline DM & 34.6 & 86.1 \\
NDF & 42.6 & 40.3 \\
CP & 7.6 & 18.3 \\
Starch & 27.7 & 4.0 \\
Ether extract & 2.8 & 1.1 \\
Ash & 5.5 & 9.3 \\
\hline
\end{tabular}

${ }^{1}$ Nutrients other than DM expressed as a percentage of diet DM.

two $4 \times 4$ Latin squares balanced for carryover effects. Treatment periods were $28 \mathrm{~d}$, with the final $9 \mathrm{~d}$ used to collect samples and data. Recombinant bST (Posilac, Monsanto, St. Louis, MO) was administered on d 1 and 15 of each period. At the beginning of the experiment, $\mathrm{BW}$ and BCS of cows were $674 \pm 97 \mathrm{~kg}$ and $2.92 \pm$ 0.36 , respectively.

Cows were offered 1 of 4 rations that differed in the amount of AH included. Alfalfa hay inclusion rates were $0,7,14$, or $21 \%$, primarily replacing CS of similar forage quality (Table 1). The strategy for formulating experimental diets was to develop diets with similar concentrations of CP, NDF, and NFC. Consequently, diets containing more $\mathrm{AH}$ had less $\mathrm{CS}$ and soybean meal but more corn grain (Table 2).

\section{Data and Sample Collection}

Throughout the experiment, cows were housed in free stalls and fed twice daily at $110 \%$ of the expected intake. Amounts of feed delivered and refused were recorded on d 19, 20, 21, 26, 27, and 28 of each period. The TMR and orts were analyzed for DM, and particle size was measured. Samples of all dietary ingredients were collected on d 19, 21, 26, and 28 and composited into 1 sample per period. Cows were milked twice daily in a milking parlor; milk was sampled and yield was recorded for every milking on d 21 and 28 of each period. Body weight and BCS were measured on d 1 of each period and d 28 of the last period. Body condition score was measured by 2 trained investigators according to procedures described by Wildman et al. (1982).

\section{Sample Analysis}

The Penn State Particle Separator was used to measure particle size for both TMR and orts (Lammers et al., 1996). Diet ingredients were dried in a $55^{\circ} \mathrm{C}$ forcedair oven for $72 \mathrm{~h}$ and analyzed for DM concentration. All samples were ground with a Wiley mill (1-mm screen, Arthur H. Thomas, Philadelphia, PA). Ash concentration was determined after $5 \mathrm{~h}$ of oxidation at $500^{\circ} \mathrm{C}$ in a muffle furnace. Concentration of NDF was determined 
Table 2. Ingredient and nutrient composition of dietary treatments

\begin{tabular}{|c|c|c|c|c|}
\hline \multirow[b]{2}{*}{ Item } & \multicolumn{4}{|c|}{ Treatment, ${ }^{1} \%$} \\
\hline & 0 & 7 & 14 & 21 \\
\hline \multicolumn{5}{|l|}{ Ingredient, \% of DM } \\
\hline Corn silage & 41.0 & 33.9 & 26.7 & 19.4 \\
\hline Alfalfa hay & 0.0 & 6.6 & 13.4 & 20.2 \\
\hline $\mathrm{WCGF}^{2}$ & 30.9 & 31.1 & 31.4 & 31.6 \\
\hline Cottonseed & 7.3 & 7.3 & 7.4 & 7.5 \\
\hline Corn grain & 9.7 & 11.6 & 13.5 & 15.6 \\
\hline Soybean meal & 4.9 & 3.4 & 1.7 & 0.0 \\
\hline Molasses & 0.4 & 0.4 & 0.4 & 0.4 \\
\hline Expeller soybean meal & 2.5 & 2.5 & 2.6 & 2.6 \\
\hline Limestone & 1.9 & 1.7 & 1.5 & 1.2 \\
\hline Micronutrient premix ${ }^{3}$ & 1.3 & 1.4 & 1.3 & 1.4 \\
\hline \multicolumn{5}{|l|}{ Nutrient $^{4}$} \\
\hline DM, \% (as fed) & 52.5 & 55.8 & 59.5 & 63.9 \\
\hline $\mathrm{CP}$ & 16.5 & 16.5 & 16.7 & 16.7 \\
\hline $\mathrm{NDF}$ & 34.6 & 34.7 & 34.5 & 34.7 \\
\hline Starch & 17.7 & 16.3 & 16.6 & 15.8 \\
\hline $\mathrm{NFC}^{5}$ & 36.0 & 36.0 & 36.4 & 36.5 \\
\hline Ether extract & 3.8 & 3.7 & 3.6 & 3.6 \\
\hline Ash & 9.1 & 9.0 & 8.8 & 8.6 \\
\hline
\end{tabular}

${ }^{1} 0 \%=0 \%$ alfalfa hay $(\mathrm{AH}) ; 7 \%=6.6 \% \mathrm{AH} ; 14 \%=13.4 \% \mathrm{AH} ; 21 \%$ $=20.2 \% \mathrm{AH}$ (DM basis).

${ }^{2}$ Wet corn gluten feed (SweetBran, Cargill Inc., Blair, NE).

${ }^{3}$ Premix consists of $48.85 \%$ sodium bicarbonate, $20.92 \%$ trace mineral salt, $10.77 \%$ magnesium oxide, $9.41 \%$ Bio-Mos (Alltech, Lexington, KY), $4.18 \%$ 4-Plex (Zinpro Corp., Eden Prairie, MN), $2.72 \%$ Se premix, $2.09 \%$ vitamin $\mathrm{E}, 0.84 \%$ vitamin $\mathrm{A}$, and $0.21 \%$ vitamin $\mathrm{D}$.

${ }^{4}$ Nutrients other than DM expressed as a percentage of diet DM.

${ }^{5}$ Calculated as DM $-(\mathrm{CP}+\mathrm{NDF}+$ ether extract + ash $)$.

(Van Soest et al., 1991; method A) by using an Ankom Fiber Analyzer (Ankom Technology, Fairport, NY). Crude protein was determined by oxidation and detection of elemental nitrogen (Leco Analyzer, Leco Corp, St. Joseph, MI). Crude fat was determined by ether extract (AOAC, 2000; method 920.9). Starch content was determined by glucoamylase digestion, followed by glucose quantification using the glucose oxidase method (Dairy One Forage Testing Laboratory, Ithaca, NY). Concentrations of all nutrients except DM were expressed as percentages of DM, as determined by drying at $105^{\circ} \mathrm{C}$ in a forced-air oven for more than $8 \mathrm{~h}$.

Milk samples were composited by day and analyzed for fat, true protein, and lactose with a B2000 Infrared Analyzer (Bentley Instruments, Chaska, MN) by Heart of America DHIA (Manhattan, KS). Energy-corrected milk $(0.327 \times$ milk yield $+12.86 \times$ fat yield +7.65 $\times$ protein yield; DHI glossary, Dairy Records Management Systems, 2007) and SCM yield were calculated (Tyrrell and Reid, 1965).

\section{Economic Model Analysis}

A break-even analysis was conducted to determine whether the added milk production from including $\mathrm{AH}$ was sufficient to justify feeding it in this type of ration. Changes in milk income, feed consumed, and feed costs were incorporated in a model to determine the relative difference in $\mathrm{AH}$ compared with $\mathrm{CS}$ value (DM basis) at different milk:feed cost ratios. Diets compared were the 0 and $21 \% \mathrm{AH}$ treatments, and production and intake means for these treatments were used in this model. The value of $\mathrm{AH}$ was fixed at $\$ 250 /$ ton of DM $(\$ 0.27 / \mathrm{kg})$, and milk value was fixed at $\$ 0.20 / \mathrm{lb}(\$ 0.44 /$ $\mathrm{kg}$ ), whereas the value of CS and TMR costs varied with the AH price differential and the milk:feed cost ratio, respectively. Addition of $21 \% \mathrm{AH}$ also allowed the exchange of $5 \%$ soybean meal for corn grain, and the cost differential between these commodities was set at $\$ 120 /$ ton of DM (soybean meal - corn grain, $\$ 0.13$ / $\mathrm{kg}$ ). Changes to the fixed values had little effect on the results as presented, although the model was somewhat sensitive to the corn grain-to-soybean meal price differential. To account for this effect of corn and soybean meal prices, we also ran the model using maximum and minimum price differentials for corn and soybean meal from 2003 to 2008 (National Agricultural Statistics Service, 2008); $\$ 120 /$ ton of DM was the mean differential for this period.

\section{Statistical Analysis}

Five cows were removed from the experiment before its completion for various reasons unrelated to treatments, and 2 replacement cows were added during periods 1 and 2. Dry matter intake was divided by the number of cows in each pen to account for missing animals.

Data were analyzed according to the following model by using the REML procedure of JMP (version 6.0, SAS Institute, Cary, NC):

$$
\mathrm{Y}_{\mathrm{ijk}}=\mu+\mathrm{P}_{\mathrm{i}}+\mathrm{T}_{\mathrm{j}}+\mathrm{N}_{\mathrm{k}}+\mathrm{PT}_{\mathrm{ij}}+\mathrm{e}_{\mathrm{ijk}},
$$

where $\mu$ is the overall mean, $P_{i}$ is the fixed effect of pe$\operatorname{riod}(\mathrm{i}=1$ to 4$), \mathrm{T}_{\mathrm{j}}$ is the fixed effect of treatment $(\mathrm{j}=$ 1 to 4$), \mathrm{N}_{\mathrm{k}}$ is the random effect of pen ( $\mathrm{k}=1$ to 8$), \mathrm{PT}_{\mathrm{ij}}$ is the interaction of period and treatment, and $\mathrm{e}_{\mathrm{ijk}}$ is the residual error. Linear and quadratic effects of treatment were tested. The interaction term was included primarily to determine if the treatment responses varied by stage of lactation. The model used to analyze milk yield responses also included the random effect of cow nested within pen, and all models were checked to ensure that no more than 18 denominator degrees of freedom were available for treatment contrasts. Treatment effects were declared significant at $P<0.05$. Tendencies for treatment effects were declared at $P<0.10$. 
Table 3. Effects of treatments on intake and performance of lactating cows

\begin{tabular}{|c|c|c|c|c|c|c|c|c|}
\hline \multirow[b]{2}{*}{ Item } & \multicolumn{4}{|c|}{ Treatment, ${ }^{1} \%$} & \multirow[b]{2}{*}{ SEM } & \multirow[b]{2}{*}{ SED } & \multicolumn{2}{|c|}{$P$-value } \\
\hline & 0 & 7 & 14 & 21 & & & Linear & Quadratic \\
\hline DMI, $\mathrm{kg} / \mathrm{d}$ & 26.7 & 27.3 & 27.4 & 27.5 & 1.16 & 0.38 & 0.05 & 0.33 \\
\hline NDF intake, $\mathrm{kg} / \mathrm{d}$ & 9.1 & 9.2 & 9.3 & 9.2 & 0.18 & 0.13 & 0.35 & 0.92 \\
\hline Milk, $\mathrm{kg} / \mathrm{d}$ & 30.9 & 31.1 & 31.7 & 31.3 & 1.48 & 0.26 & $0.03^{*}$ & $0.16^{*}$ \\
\hline $\mathrm{SCM}, \mathrm{kg} / \mathrm{d}$ & 29.9 & 30.2 & 30.8 & 30.5 & 1.36 & 0.40 & 0.07 & 0.30 \\
\hline ECM, $\mathrm{kg} / \mathrm{d}$ & 32.9 & 33.3 & 33.8 & 33.6 & 1.45 & 0.43 & 0.09 & 0.32 \\
\hline ECM/DMI & 1.16 & 1.14 & 1.16 & 1.15 & 0.03 & 0.02 & 0.75 & 0.88 \\
\hline BW change, $\mathrm{kg} / 28 \mathrm{~d}$ & 23.0 & 18.0 & 11.2 & 9.5 & 3.6 & 5.7 & 0.02 & 0.69 \\
\hline $\mathrm{BCS}$ change $/ 28 \mathrm{~d}$ & 0.014 & 0.031 & -0.006 & -0.013 & 0.041 & 0.065 & 0.57 & 0.80 \\
\hline
\end{tabular}

${ }^{1} 0 \%=0 \%$ alfalfa hay $(\mathrm{AH}) ; 7 \%=6.6 \% \mathrm{AH} ; 14 \%=13.4 \% \mathrm{AH} ; 21 \%=20.2 \% \mathrm{AH}$ (DM basis).

$*$ Significant treatment $\times$ period interaction.

\section{RESULTS AND DISCUSSION}

\section{Ration Composition, Feed Intake, and Milk Production}

Final analyses showed that nutrient composition of diets remained similar across all 4 treatments, with DM increasing and starch decreasing slightly as more $\mathrm{AH}$ was added (Table 2). Adding more $\mathrm{AH}$ to the ration tended to linearly increase DMI as well as ECM and SCM yields (Table 3). Statistical analysis of milk yield showed a significant treatment $\times$ period interaction. Cows in this study averaged 290 DIM at the end of the study, and not surprisingly, milk yield declined during the study; however, this interaction suggested that greater $\mathrm{AH}$ inclusion may have supported improved persistence in late lactation. Cows receiving 14 and $21 \%$ AH maintained milk production better through period 4 (means of $28.4,28.3,31.1$, and $30.9 \mathrm{~kg} / \mathrm{d}$ for 0 , 7,14 , and $21 \% \mathrm{AH}$, respectively). However, we are not aware of full-lactation studies demonstrating improved persistence with AH-based diets, and given that period $x$ treatment interactions were not observed for ECM or FCM yields, this result should be interpreted with caution.
Feed efficiency, as measured as ECM/DMI, averaged $1.15 \pm 0.03$ and was similar across treatments. The low feed efficiency in this study was likely primarily because relatively late-lactation cows were used. Feed efficiency ratios have often exceeded 1.3 in other studies investigating diets with high inclusion rates of corn gluten feed (Ohajuruka and Palmquist, 1989; Schroeder, 2003; Kononoff et al., 2006).

Fat and protein percentages and yield were not affected by treatment $(P>0.15$; Table 4$)$. Concentrations of milk fat and protein averaged $3.78 \pm 0.11$ and 3.45 $\pm 0.07 \%$, respectively, and yield of these components averaged $1.17 \pm 0.06$ and $1.07 \pm 0.03 \mathrm{~kg} / \mathrm{d}$, respectively (Table 4). We observed a significant linear effect of $\mathrm{AH}$ on lactose yield, which was consistent with the tendency for increased SCM yield with higher alfalfa inclusion rates. There was a quadratic effect of $\mathrm{AH}$ inclusion rate on MUN $(P=0.05)$; however, the range of means was very small and the response did not correspond with treatment effects on dietary $\mathrm{CP}$ or milk protein yield; therefore, there is no clear explanation for this observation.

Lack of a significant treatment effect on milk fat yield or concentration suggests that ruminal biohy-

Table 4. Effects of treatments on milk components

\begin{tabular}{|c|c|c|c|c|c|c|c|c|}
\hline \multirow[b]{2}{*}{ Item } & \multicolumn{4}{|c|}{ Treatment, ${ }^{1} \%$} & \multirow[b]{2}{*}{ SEM } & \multirow[b]{2}{*}{ SED } & \multicolumn{2}{|c|}{$P$-value } \\
\hline & 0 & 7 & 14 & 21 & & & Linear & Quadratic \\
\hline Milk fat, $\%$ & 3.75 & 3.81 & 3.75 & 3.79 & 0.11 & 0.08 & 0.79 & 0.83 \\
\hline Milk protein, \% & 3.47 & 3.46 & 3.44 & 3.44 & 0.07 & 0.03 & 0.38 & 0.84 \\
\hline Lactose, \% & 4.77 & 4.75 & 4.81 & 4.76 & 0.03 & 0.02 & 0.64 & 0.44 \\
\hline SCC, $\log$ & 2.17 & 2.19 & 2.18 & 2.22 & 0.06 & 0.05 & 0.46 & 0.80 \\
\hline MUN, mg/dL & 12.6 & 13.0 & 12.7 & 12.5 & 0.48 & 0.22 & 0.31 & 0.05 \\
\hline $\begin{array}{l}\text { Yield, kg/d } \\
\text { Milk fat }\end{array}$ & & & & & & & & \\
\hline Milk fat & 1.14 & 1.17 & 1.18 & 1.18 & 0.06 & 0.03 & 0.21 & 0.44 \\
\hline Milk protein & 1.06 & 1.06 & 1.08 & 1.07 & 0.03 & 0.01 & 0.15 & 0.48 \\
\hline Milk lactose & 1.48 & 1.48 & 1.54 & 1.51 & 0.08 & 0.02 & 0.02 & 0.18 \\
\hline
\end{tabular}


Table 5. Particle size separation (as-fed basis) ${ }^{1}$

\begin{tabular}{lcccc}
\hline & \multicolumn{4}{c}{ Treatment, $^{2} \%$} \\
\cline { 2 - 5 } Item & 0 & 7 & 14 & 21 \\
\hline TMR & & & & \\
$>19 \mathrm{~mm}$ & $2.2^{\mathrm{a}}$ & $4.5^{\mathrm{a}}$ & $9.5^{\mathrm{b}}$ & $14.1^{\mathrm{c}}$ \\
$19>8 \mathrm{~mm}$ & $39.1^{\mathrm{b}}$ & $36.6^{\mathrm{b}}$ & $30.5^{\mathrm{a}}$ & $26.8^{\mathrm{a}}$ \\
$<8 \mathrm{~mm}$ & $58.7^{3}$ & 58.9 & 60.0 & $59.1^{3}$ \\
Orts $^{3}$ & $2.7^{\mathrm{a}}$ & $10.5^{\mathrm{b}}$ & $20.5^{\mathrm{c}}$ & $24.5^{\mathrm{c}}$ \\
$>19 \mathrm{~mm}$ & $48.6^{\mathrm{c}}$ & $39.4^{\mathrm{b}}$ & $32.1^{\mathrm{a}}$ & $28.6^{\mathrm{a}}$ \\
$19>8 \mathrm{~mm}$ & 48.8 & 50.1 & 47.3 & 46.9 \\
$<8 \mathrm{~mm}$ & & & \\
\hline
\end{tabular}

${ }^{\mathrm{a}-\mathrm{c}}$ Means with different superscripts within a row are significantly different by Tukey's HSD $(P<0.05)$.

${ }^{1}$ Measured with a 3-compartment Penn State Particle Size Separator (Lammers et al., 1996).

${ }^{2} 0 \%=0 \%$ alfalfa hay $(\mathrm{AH}) ; 7 \%=6.6 \% \mathrm{AH} ; 14 \%=13.2 \% \mathrm{AH} ; 21 \%$ $=20.2 \% \mathrm{AH}$ ( $\mathrm{DM}$ basis $)$.

${ }^{3}$ Mean refusal amounts ranged from 3.5 to $4.2 \mathrm{~kg} / \mathrm{cow}$ daily (approximately $15 \%$ of what was offered) and did not vary by treatment $(P$ $>0.30)$.

drogenation was not inhibited in diets with lower $\mathrm{AH}$ inclusion rates, which agrees with the results reported by Kleinschmit et al. (2007). In our study, NDF intake was not altered by treatment $(P>0.35$; Table 3$)$, but diets with more AH offered greater proportions of particles longer than $19 \mathrm{~mm}$, which would be expected to increase the physical effectiveness of NDF. However, cows sorted against longer particles in the diets with more AH (Table 5), which is consistent with previous research (Methu et al., 2001; Leonardi and Armentano, 2003). It is not possible to determine whether sorting occurred because of the difference in TMR moisture or because more long particles were offered. Regardless, the fact that cows sorted against large particles may help explain why milk fat production remained similar across treatments, despite large differences in the physical effectiveness of fiber in the diets as fed.

Production responses to replacement of CS with AH have been inconsistent. This is not surprising, given that different formulation strategies can dramatically influence factors such as particle size, protein degradability, and fiber digestibility when $\mathrm{AH}$ is added. Kleinschmit et al. (2007) reported a linear increase in milk yield when AH replaced CS in a diet including 15\% (DM) distillers dried grains with solubles. In contrast, Kowsar et al. (2008) reported that when finely chopped AH partially replaced CS, DMI and milk, protein, and lactose yields all decreased. Diets based on WCGF may provide the ideal setting for removal of $\mathrm{AH}$. Wet corn gluten feed is a source of highly degradable protein (Kononoff et al., 2007), making the loss of RDP from AH less detrimental. Additionally, despite concerns about the lack of physically effective fiber in such diets, they also tend to contain less starch than typical lactation rations, which may help prevent acidosis-related problems associated with the loss of long-stem AH. Nevertheless, our findings generally agree with those of Kleinschmit et al. (2007), with higher AH inclusion rates tending to increase FCM production.

\section{Energetics}

Body condition score was not significantly affected by dietary treatment $(P>0.57$; Table 3$)$. However, cows fed TMR containing more $\mathrm{AH}$ gained less BW compared with cows fed less AH $(P=0.02)$. As AH was added to the ration, energy partitioning changed from BW gain to milk production, and total energy for production and gain tended to decrease linearly $(P=$ 0.06; Figure 1). Diets with more AH and less CS were not as fermentable (Holden, 1999), which likely decreased ruminal production of propionate. Propionate stimulates insulin secretion both directly and through stimulation of gluconeogenesis, and lactating cows fed more fermentable diets often have higher plasma insulin concentrations (Grant et al., 1990). Decreased fermentability in the high-AH treatments may have decreased plasma insulin, resulting in decreased lipogenesis in adipose tissue (Oba and Allen, 2003). However, blood samples were not collected during this study, so this hypothesis cannot be confirmed.

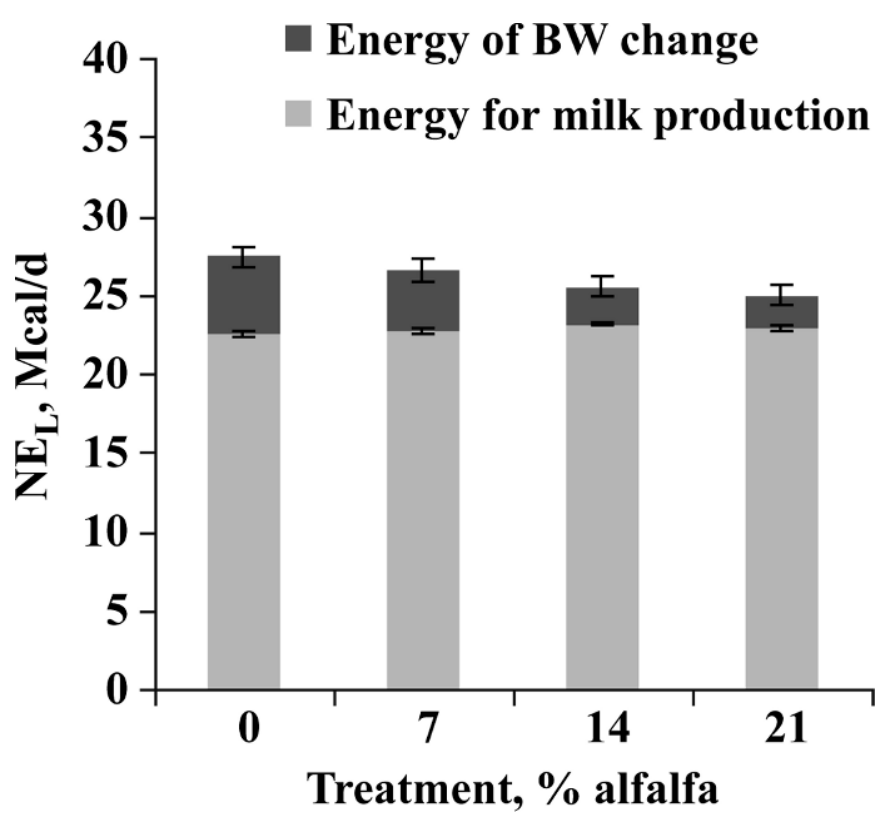

Figure 1. Total energy partitioned to milk production and BW gain in cows fed varying levels of alfalfa hay $(\mathrm{AH})$. As $\mathrm{AH}$ was added, total energy utilization tended $(P=0.06)$ to decrease linearly. Body weight gain was assigned an energetic value of $5.975 \mathrm{Mcal} / \mathrm{kg}$ (NRC, 2001), and milk energy was calculated according to Tyrrell and Reid (1965). 


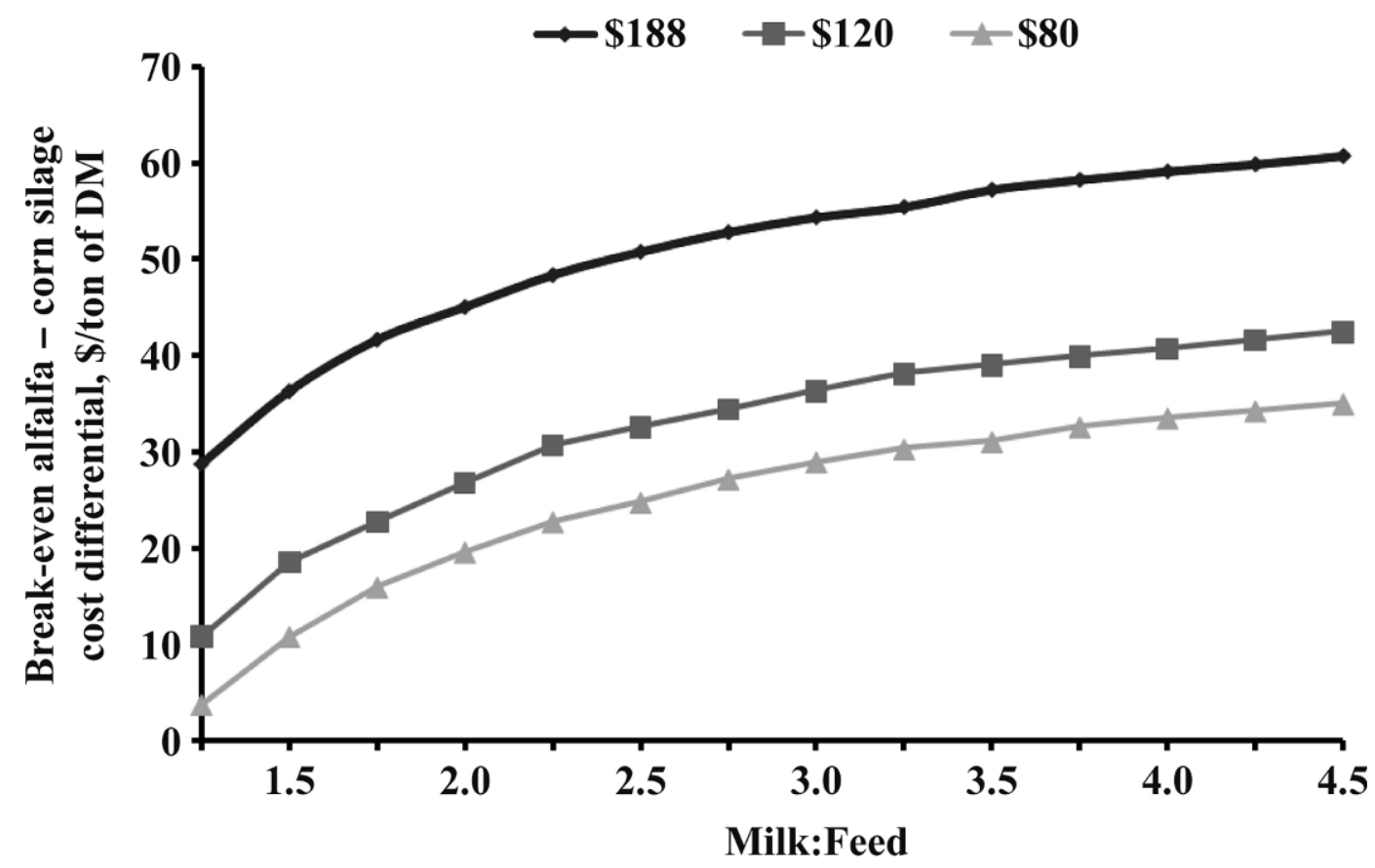

Figure 2. Break-even analysis of the alfalfa hay (AH)-to-corn silage (CS) cost differential. Break-even analysis was conducted to determine whether the added milk production from including AH was sufficient to justify feeding it in this type of ration. The line indicates the break-even additional cost that can be paid for alfalfa compared with CS (per ton of DM) at a given milk:feed cost ratio. Values were calculated by using milk production and DMI data from the 0 and $21 \%$ alfalfa diets. The 3 lines represent the minimum $(\$ 80)$, mean $(\$ 120)$, and maximum (\$188) corn-soybean meal price differential from 2003 to 2008.

\section{Manure Production}

Fecal output was not monitored in this study, but on the basis of previous findings (Weiss et al., 2007), we speculate that manure production was likely influenced. Figure 1 represents the total energy used for production and BW gain of cows consuming each TMR; the tendency for decreased energy yield in the face of increasing DMI strongly suggests that the diets containing more $\mathrm{AH}$ were less digestible, which is not surprising given that a dried hay replaced an ensiled forage in these diets (Holden, 1999). Because fecal production is highly dependent on DM digestibility, increased manure production is one likely result of incorporating $\mathrm{AH}$ in rations similar to those used in this study.

\section{Economic Analysis}

Although feeding greater levels of $\mathrm{AH}$ tended to increase ECM production, it also led to greater DMI. The potential economic effects of such a response were evaluated to determine the theoretical value of $\mathrm{AH}$ relative to CS. According to the break-even analysis presented in Figure 2, if the price differential between $\mathrm{AH}$ and CS falls below the line at a given milk:feed cost ratio, it is profitable to incorporate $\mathrm{AH}$ into this type of ration. However, on the basis of responses to the 0 and $21 \%$ alfalfa treatments in this study, adding $\mathrm{AH}$ to diets with high WCGF inclusion rates may not be profitable, especially when milk:feed cost ratios are low. This analysis suggests that even with favorable milk:feed cost ratios and expensive soybean meal, $\mathrm{AH}$ should demand no more than a $\$ 60$ premium per ton of DM to be incorporated into similar rations. Additionally, this analysis ignores costs associated with predicted increases in manure output and costs (or benefits) of decreased BW gain when more AH is fed.

\section{CONCLUSIONS}

Feeding higher proportions of $\mathrm{AH}$ tended to increase ECM yield and decrease BW gain, suggesting that ME supply was repartitioned from BW gain to milk production as more AH was included. Nonetheless, decreasing the $\mathrm{AH}$ inclusion rate may improve farm profitability by reducing feed costs and expenses associated with manure handling, despite small losses in productivity.

\section{ACKNOWLEDGMENTS}

The authors express their appreciation to Mike Scheffel, Cheryl Armendariz, Scott Morey, and Sydney Janssen for their assistance with this trial and to Cargill Inc. for donation of the Sweet Bran. 


\section{REFERENCES}

Allen, D. M., and R. J. Grant. 2000. Interactions between forage and wet corn gluten feed as sources of fiber in diets for lactating dairy cows. J. Dairy Sci. 83:322-331.

AOAC. 2000. Official Methods of Analysis. 17th ed. Assoc. Off. Anal. Chem., Arlington, VA.

Armentano, L. E., and M. R. Dentine. 1988. Wet corn gluten feed as a supplement for lactating dairy cattle and growing heifers. J. Dairy Sci. 71:990-995.

Dairy Records Management Systems. 2007. DHI Glossary. http:// www.drms.org/PDF/materials/glossary.pdf Accessed on Nov 10, 2007.

Grant, R. J., V. F. Colenbrander, and D. R. Mertens. 1990. Milk fat depression in dairy cows: Role of silage particle size. J. Dairy Sci. 73:1834-1842.

Hayden, C. C., C. F. Monroe, and A. E. Perkins. 1933. Silage without hay for dairy cows. Page 64 in Proc. Am. Dairy Sci. Assoc. Annu. Mtg. Am. Dairy Sci. Assoc., Urbana, IL. (Abstr.)

Holden, L. A. 1999. Comparison of methods of in vitro dry matter digestibility for ten feeds. J. Dairy Sci. 82:1791-1794.

Kay, R. N. 1966. The influence of saliva on digestion in ruminants. World Rev. Nutr. Diet. 6:292-325.

Kleinschmit, D. H., D. J. Schingoethe, A. R. Hippen, and K. F. Kalscheur. 2007. Dried distillers grains plus solubles with corn silage or alfalfa hay as the primary forage source in dairy cow diets. J. Dairy Sci. 90:5587-5599.

Kononoff, P. J., S. Ivan, W. Matzke, R. J. Grant, R. Stock, and T. J. Klopfenstein. 2006. Milk production of dairy cows fed a wet corn gluten feed during the dry period and lactation. J. Dairy Sci. 89:2608-2617.

Kononoff, P. J., S. K. Ivan, and T. J. Klopfenstein. 2007. Estimation of the proportion of feed protein digested in the small intestine of cattle consuming wet corn gluten feed. J. Dairy Sci. 90:23772385 .

Kowsar, R., G. R. Ghorbani, M. Alikhania, M. Khorvash, and A. Nikkhah. 2008. Corn silage partially replacing short alfalfa hay to optimize forage use in total mixed rations for lactating cows. J Dairy Sci. 91:4755-4764.

Lammers, B. P., D. R. Buckmaster, and A. J. Heinrichs. 1996. A simple method for the analysis of particle sizes of forage and total mixed rations. J. Dairy Sci. 79:922-928.

Leonardi, C., and L. E. Armentano. 2003. Effect of quantity, quality, and length of alfalfa hay on selective consumption by dairy cows. J. Dairy Sci. 86:557-564.
Mertens, D. R. 1997. Creating a system for meeting the fiber requirements of dairy cows. J. Dairy Sci. 80:1463-1481.

Methu, J. N., E. Owen, A. L. Abate, and J. C. Tanner. 2001. Botanical and nutritional composition of maize stover, intakes and feed selection by dairy cattle. Livest. Prod. Sci. 71:87-96.

Mowrey, A., and J. N. Spain. 1999. Results of a nationwide survey to determine feedstuffs fed to lactating dairy cows. J. Dairy Sci. $82: 445-451$.

National Agricultural Statistics Service. 2008. QuickStats. http://www. nass.usda.gov/QuickStats/index2.jsp Accessed Aug. 21, 2008.

NRC. 2001. Nutrient Requirements of Dairy Cattle. 7th rev. ed. Natl. Acad. Sci., Washington, DC.

Oba, M., and M. S. Allen. 2003. Effects of corn grain conservation method on feeding behavior and productivity of lactating dairy cows at two dietary starch concentrations. J. Dairy Sci. 86:174183.

Ohajuruka, O. A., and D. L. Palmquist. 1989. Response of highproducing dairy cows to high levels of dried corn gluten feed. Anim. Feed Sci. Technol. 24:191-200.

Schroeder, J. W. 2003. Optimizing the level of wet corn gluten feed in the diet of lactating dairy cows. J. Dairy Sci. 86:844-851.

Staples, C. R., C. L. Davis, G. C. McCoy, and J. H. Clark. 1984. Feeding value of wet corn gluten feed for lactating dairy cows. J. Dairy Sci. 67:1214-1220.

Thomas, J. W., L. D. Brown, and R. S. Emery. 1970. Corn silage compared to alfalfa hay for milking cows when fed various levels of grain. J. Dairy Sci. 53:342-350.

Tyrrell, H. F., and J. T. Reid. 1965. Prediction of the energy value of cow's milk. J. Dairy Sci. 48:1215-1223.

Van Soest, P. J., J. B. Robertson, and B. A. Lewis. 1991. Methods for dietary fiber, neutral detergent fiber, non-starch polysaccharides in relation to animal nutrition. J. Dairy Sci. 74:3583-3597.

Weiss, W. P., N. R. St-Pierre, and L. B. Willet. 2007. Factors affecting manure output on dairy farms. Pages 55-62 in Proc. Tri-State Dairy Nutr. Conf., Ft. Wayne, IN. The Ohio State University, Columbus.

Wickersham, E. E., J. E. Shirley, E. C. Titemeyer, M. J. Brouk, J. M. DeFrain, A. F. Park, D. E. Johnson, and R. T. Ethington. 2004. Response of lactating dairy cows to diets containing wet corn gluten feed or a raw soybean hull-corn steep liquor pellet. J. Dairy Sci. 87:3899-3911.

Wildman, E. E., G. M. Jones, P. E. Wagner, R. L. Boman, H. F. Troutt Jr., and T. N. Lesch. 1982. A dairy cow body condition scoring system and its relation to selected production characteristics. J. Dairy Sci. 65:495-501. 